\title{
A combined geophysical and lithological study on eruptive history and Quaternary lacustrine stratigraphy of a maar in Leizhou Peninsula, China
}

\author{
Cong Chen ${ }^{1}$, Zhuo Zheng ${ }^{1,2^{*}}$ (D) Li-Feng Zeng ${ }^{1}$, Fan Xiao ${ }^{1}$, Li-Ping Tian ${ }^{1}$ and Kang-You Huang ${ }^{1,2}$
}

\begin{abstract}
As the second common type of volcanic vent on Earth, maar-diatreme volcanoes and their post-eruptive lacustrine sediments are a main focus of volcanology, palaeolimnology, palaeoclimatology and palaeontology. A number of maar-type volcanoes have been found in Leizhou Peninsula, South China, but little is known about their eruption processes and detailed stratigraphy of the post-eruptive sediments. We present a combined geophysical and geological analysis to study the eruptive history and post-eruptive sediment stratigraphy of a large maar, the elliptical $\left(1.8 \times 3.0 \mathrm{~km}^{2}\right)$ Jiudouyang (JDY) maar. The lacustrine stratigraphy revealed by drilling cores shows that the JDY maar lake has three major stages of evolution: (i) deep-lake sedimentary environment characterized by high autochthonous diatom productivity; (ii) shallow lake to swamp with very low water levels, characterized by a high total organic carbon (TOC) and abundant wood fragments; and, (iii) intermittent shallow lake and alluvial deposits composed of clay minerals and sand. The electrical resistivity tomography (ERT) values and lithological features are highly consistent, which clearly reveal the presence of ca. $50 \mathrm{~m}$ thick lacustrine sediments, directly underlain by a ca. $70 \mathrm{~m}$ thick basaltic lava rather than diatreme breccia in the crater. This infill sequence implies an alternation of eruption style from phreatomagmatic to Strombolian and/or lava flow, due to high magma flux and ascent rate of the Hainan Plume during the middle Pleistocene. The ERT data also reveal the initial phreatomagmatic crater floor at ca. $120 \mathrm{~m}$ depth. The initial crater had a large diameter/depth ratio (ca. 17), with an elongated shape (major axis to minor axis=0.6), implying possible lateral vent migration during the eruption. A significant erosion under tropical weathering condition during the last few hundred thousand years, accounted for the large size of the maar crater. The study provides insights into the eruptive history and post-eruptive evolution of a large maar, as well as the spatial distribution of the lacustrine sediments.
\end{abstract}

Keywords: Maar crater, Eruptive history, Infill sequence, Lake evolution, Lacustrine stratigraphy, Leizhou Peninsula

\footnotetext{
* Correspondence: eeszzhuo@mail.sysu.edu.cn

'Guangdong Provincial Key Lab of Geodynamics and Geohazards, School of Earth Sciences and Engineering, Sun Yat-sen University, Guangzhou 510275, Guangdong Province, China

${ }^{2}$ Southern Marine Science and Engineering Guangdong Laboratory (Zhuhai), Zhuhai 519082, Guangdong Province, China
}

\section{Springer Open}

(c) The Author(s). 2021 Open Access This article is licensed under a Creative Commons Attribution 4.0 International License, which permits use, sharing, adaptation, distribution and reproduction in any medium or format, as long as you give appropriate credit to the original author(s) and the source, provide a link to the Creative Commons licence, and indicate if changes were made. The images or other third party material in this article are included in the article's Creative Commons licence, unless indicated otherwise in a credit line to the material. If material is not included in the article's Creative Commons licence and your intended use is not permitted by statutory regulation or exceeds the permitted use, you will need to obtain permission directly from the copyright holder. To view a copy of this licence, visit http://creativecommons.org/licenses/by/4.0/. 


\section{Introduction}

Maar-diatreme volcanoes are the second common type of volcanic vent on Earth (Lorenz 2007). These volcanoes and the post-eruptive lacustrine sediments are a main focus of the volcanology, palaeolimnology, palaeoclimatology and palaeontology. The morphology of maar craters is governed by the sub-surface phreatomagmatic explosion (Oms et al. 2015). Lorenz (1986) suggested that their diameter is determined by syn-eruptive subsidence and a large maar crater is accompanied by a large sub-surface diatreme, with a crater diameter to diatreme depth ratio of 1:1. However, as noted by Valentine and White (2012), crater diameter is influenced by numerous factors, including magma flux, vent migration, ejection of material and subsidence of failed crater walls. In addition, craters' diameter to depth ratios reportedly increase with age due to widening and reduction in heights by erosion (e.g., Gençalioğlu-Kuşcu et al. 2007) and/or vent migration during eruption (e.g., Jordan et al. 2013). These processes are complex, but the morphological characteristics of maar craters and the eruption products are keys to indicating the volcanic process and associated eruption environments (Graettinger 2018; Xian et al. 2018).

Most studies on maar-diatreme systems have focused on cases where the craters have an ejecta ring with limited erosion, or sub-surface structures are exposed, which can therefore be relatively easily examined (White and Ross 2011; and references therein). However, subsurface structures of maar-diatreme volcanoes with extremely weathered and eroded ejecta rings can only be modeled or investigated using geophysical approaches and boreholes (e.g., Schulz et al. 2005; Mrlina et al. 2009; Gebhardt et al. 2011; Blaikie et al. 2014). An efficient and convenient geophysical method that has been widely used to image internal structures, substrates and post-volcanic stratigraphy of maar-diatreme volcanoes, is the electrical resistivity tomography (ERT) (e.g., Brunner et al. 1999; Oms et al. 2015). ERT surveying, in combination with other geophysical methods and geological techniques, can accurately characterize uppermost parts of maars to help efforts to: elucidate effects of the preeruptive substrate (Martín-Serrano et al. 2009); determine the distribution of post-eruptive sediments and the depocentre for palaeoclimatic drilling (Flechsig et al. 2015); and locate the sub-surface structures to reveal the eruptive history (Bolós et al. 2012).

Maar-diatreme structures can host long-lived and climate-sensitive lakes, which are significant in palaeoclimatic and palaeoenvironmental researches (White and Ross 2011; Chu and Liu 2018; Wu et al. 2019). Maar lake basins are endorheic basins with relatively small drainage areas, where the major input is from meteoric precipitation and/or groundwater. This makes them sensitive to local and regional climate change (e.g., Mingram et al. 2004). Moreover, maar lakes are especially suitable for preserving long-term continuous and high temporal resolution (seasonal to annual) records since their morphology (e.g., small diameter and deep depth) favors the rapid and continuous accumulation of sediments (e.g., Zolitschka 1992; Ortiz et al. 2013). The annually laminated sediments of maar lakes, like ice cores and tree rings, can provide an independently reliable chronology for palaeoenvironmental reconstruction (e.g., Brauer et al. 1999; Chu et al. 2008). Finally, their sediments are of high value for multi-proxy studies, including palaeontological indicators (e.g., pollen and diatoms) and geophysical (e.g., magnetic properties) and geochemical parameters (e.g., major and trace elements, stable isotopes of oxygen and carbon), of palaeoclimatic and palaeoenvironmental changes (Chu and Liu 2018; Wu et al. 2019).

The volcanic field distributed from Leizhou Peninsula to the northern part of Hainan Island is the largest Quaternary basaltic province in southern China (Ho et al. 2000). In respect of tectonic evolution, the formation of this volcanic field is a result of regional faults caused by Cenozoic opening of the South China Sea and the upwelling of the Hainan Plume (Yu et al. 2018). There are more than 150 volcanoes, including stratovolcanoes, shield volcanoes and maar-diatreme volcanoes (Huang et al. 1993). In particular, there are several known maars with large average diameter, such as Tianyang $(>3 \mathrm{~km})$, Qingtongyang $(>2 \mathrm{~km})$, Jiudouyang $(>2 \mathrm{~km})$, and Huguangyan $(>2 \mathrm{~km})$. According to the recently compiled Maar Volcano Location and Shape (MaarVLS) database, maars with $>2 \mathrm{~km}$ diameter only account for $12 \%$ of the total (29 out of 239), most of which are located in mid- to high-latitudes (Graettinger 2018). In recent decades, a number of important advances in palaeoenvironmental understanding have been obtained from analyses of the maar lacustrine sediments in Leizhou Peninsula and Hainan Island (e.g., Zheng and Lei 1999; Liu et al. 2000; Zheng et al. 2003; Yancheva et al. 2007; Chu et al. 2017). However, the eruptive history and lake-peat evolution of the large maars in this lowlatitude coastal area have received little attention (Sun and Fan 2005), and there is no information on the thickness and spatial distributions of the post-volcanic lacustrine sediments in many dry maar lakes.

Thus, in the study presented here, the Jiudouyang (JDY) maar in the middle of Leizhou Peninsula was subjected to electrical resistivity tomography (ERT) imaging, and a core was drilled in the centre of the maar crater. Unfortunately, little geological information about eruptive products is available because of extreme weathering in tropical hot and humid climate. However, the ERT data and the core lithology provide accurate indications 
of eruptive history and lake-peat evolution of the maar volcano, and the thickness and spatial distributions of the post-volcanic lacustrine sediments. Moreover, the results may also extend a general understanding of the evolution of maar-diatreme volcanoes, superficial lacustrine sediments and Quaternary palaeoenvironments.

\section{Geological setting}

Volcanic rocks, including basaltic and pyroclastic rocks covers a large area around the South China Sea (Fig. 1a). According to ${ }^{40} \mathrm{Ar} /{ }^{39} \mathrm{Ar}$ and $\mathrm{K} / \mathrm{Ar}$ age dating results, the major volcanic eruptions began in the Oligocene, peaked in the middle Pleistocene, and finally ended in the Holocene (Huang et al. 1993; Ho et al. 2000; Yu et al. 2018). The geochemical composition of the basalts suggests that they consist of a mixture of upwelling mantle materials and terrestrial sediments, possibly originating from the opening of the South China Sea associated with lithospheric stretching followed by magma rising and consequent volcanic activities (Tu et al. 1991). An alternative explanation, based on geophysical evidences, involving the action of a mantle plume beneath LeizhouHainan region, has also been proposed (Lebedev et al. 2000; Wei and Chen 2016). The Hainan Plume contributed to continental breakup and seafloor spreading since ca. 23.8 $\mathrm{Ma}$ (Yu et al. 2018). In addition, isotope studies of Holocene basalts suggest that the magma upwelling from the lower mantle was slow $(<1 \mathrm{~cm} /$ year $)$, indicating that the Hainan Plume was a dying plume (Zou and
Fan 2010). The tectonic evolution of Leizhou Peninsula was mostly controlled by NW-SE and W-E trending faults, and the volcanism was aligned with these faults (Fig. 1a) (Flower et al. 1992; Huang et al. 1993; Huang and Chai 1994). The dominant eruptive types in Leizhou-Hainan region included Strombolian, Hawaiian and phreatomagmatic eruption (Huang et al. 1993).

The Jiudouyang (JDY) maar is situated in the middle of Leizhou Peninsula (Fig. 1b). The altitude of the present-day crater floor is $58 \mathrm{~m}$ a.s.l. (above sea level), and the average height of the ejecta ring is ca. $20 \mathrm{~m}$. The ejecta ring is asymmetrical, being lowest in the north, and the internal slopes are steeper in the east than in the west (Fig. 2). The elliptical crater has been infilled with lacustrine sediments and covers an area of ca. 4.5 $\mathrm{km}^{2}$, with major and minor axes of ca. $3.0 \mathrm{~km}$ and ca. $1.8 \mathrm{~km}$, respectively (Fig. 2). According to the classification scheme of Gevrek and Kazanci (2000), the JDY maar is "large" (diameter $>1000 \mathrm{~m}$ ). However, we have less knowledge of the JDY maar than other large maars (e.g., Tianyang and Huguangyan maars) in Leizhou Peninsula, and the age of this maar-diatreme volcano is poorly constrained. Liu (1999) inferred that it erupted in the middle Pleistocene, based on the contact relationship of basalts and country rocks. Recently, two conflicting $\mathrm{K}-\mathrm{Ar}$ ages (0.81 Ma and $1.08 \mathrm{Ma}$, respectively) were reported from basalts at ca. $50 \mathrm{~m}$ depth of the crater (Wang and Lu 2019). The country rocks are dominated by Quaternary sedimentary deposits, including the

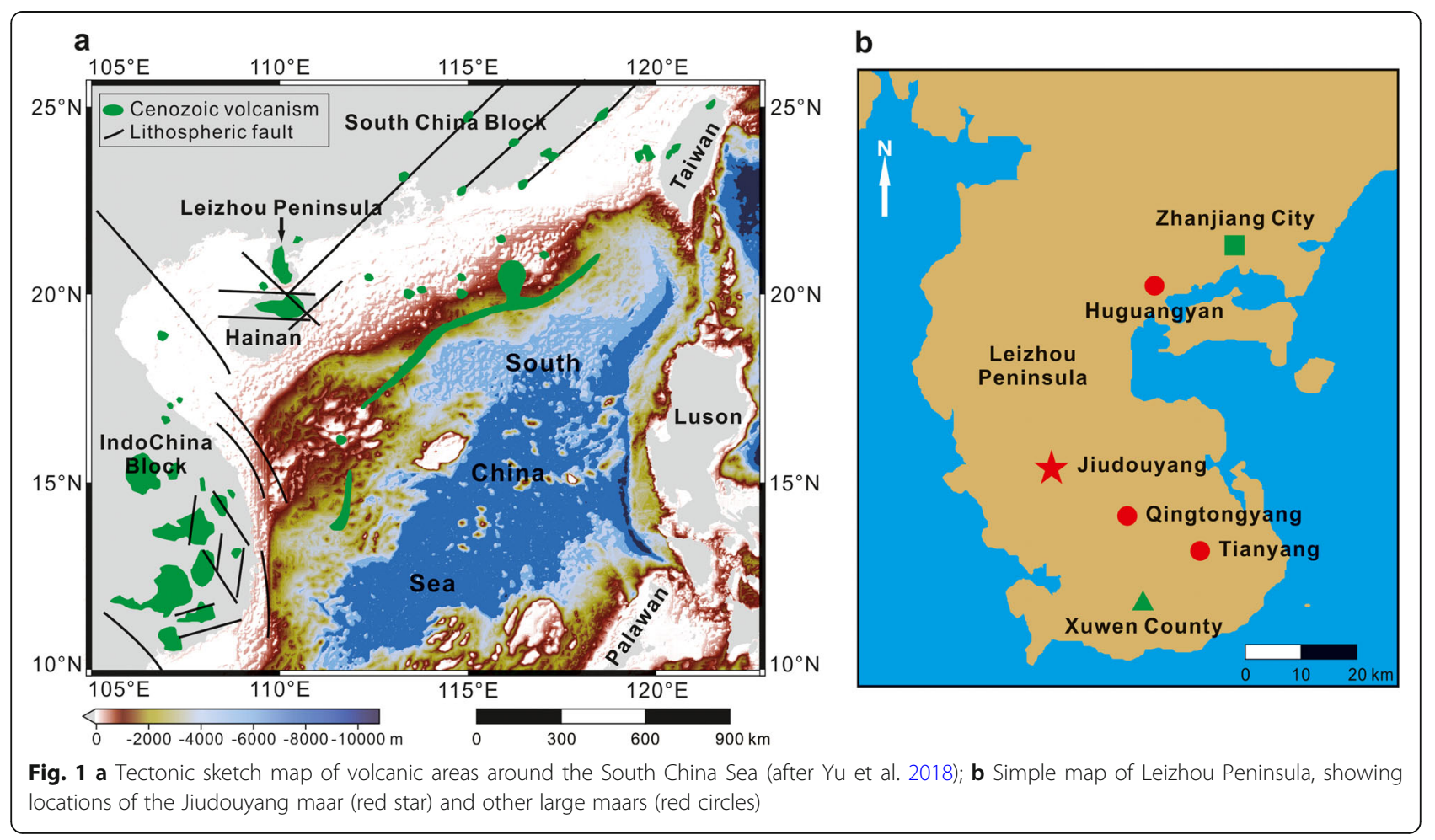




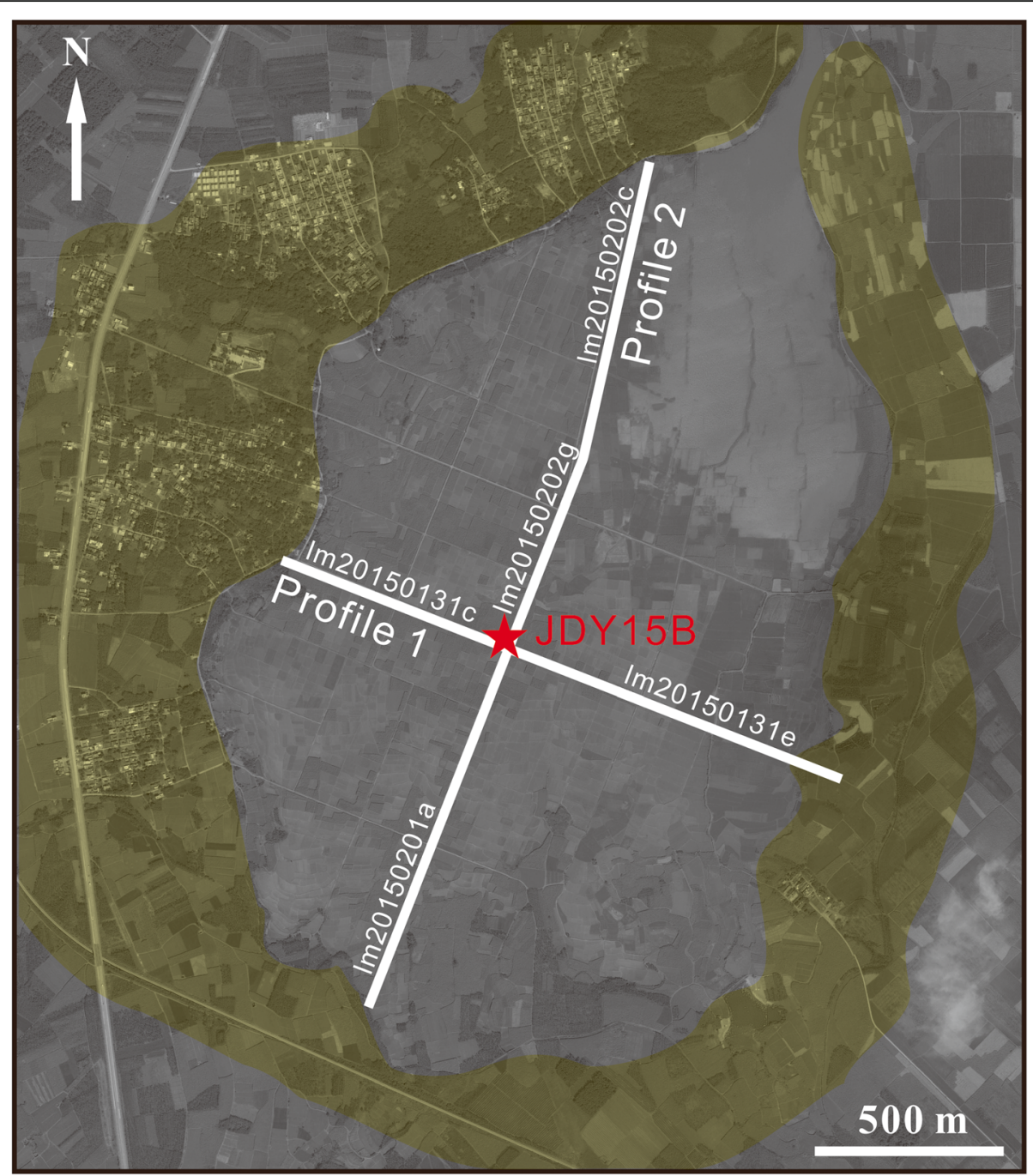

Fig. 2 Orthophoto map of the Jiudouyang maar, showing locations of the JDY15B core (red star) and the two crossed profiles (white lines). The yellow shade indicates the present-day ejecta ring, which has an artificial outlet in northeast

Zhanjiang Formation (littoral clay layers, ca. $0.8 \mathrm{Ma}$ ) and the Beihai Formation (alluvial sand-gravel layers, ca. 0.55 Ma) (Huang et al. 1993). Nevertheless, the JDY maar crater potentially accumulated lacustrine sediments covering several hundred thousand years and provides an important terrestrial palaeoclimatic record on glacialinterglacial timescale from tropical East Asia. In the past years, two earthquakes occurred near the JDY maar, with Richter magnitudes of 3.1 and 3.6, respectively, highlighting a need for greater understanding of the neo-tectonic activity in the region.

\section{Methods}

3.1 Electrical resistivity tomography (ERT) data acquisition Multi-electrode ERT was applied to obtain high-resolution 2-D resistivity data on the JDY maar in January 2015. Data were acquired with a new WGMD-9
Multi-electrode Resistivity Imaging System produced by the Benteng Digital Control Technical Institute (Chongqing, China). We used a Wenner array with 120 electrodes (10 m spacing) connected to an 1190 $\mathrm{m}$-long cable. This array provides a good signal-tonoise ratio and high sensitivity to vertical resistivity variations with smaller acquisition times (Dahlin and Zhou 2004; Martorana et al. 2009). Thus, it offered opportunities for a relatively precise correlation of the ERT results with core stratigraphy and relatively accurate determination of the thickness of crater-filling units. Two profiles were obtained, one along the minor axis (Profile 1) and the other along the major axis (Profile 2) of the crater, with five segments in total (Fig. 2; Table 1). However, the ejecta ring was not covered by these profiles due to the obstruction by the Jiudouyang village and railway. In our survey, the contact resistances were kept low (maximum 
Table 1 Details of the electrical resistivity tomography profiles

\begin{tabular}{|c|c|c|c|c|c|}
\hline Profile & Segment & Length $(\mathrm{m})$ & RMS error (\%) & Overlapping (m) & Total length (m) \\
\hline \multirow[t]{2}{*}{ Profile 1} & Im20150131c & 990 & 7.5 & 500 & 1590 \\
\hline & Im20150131e & 1090 & 5.7 & & \\
\hline \multirow[t]{3}{*}{ Profile 2} & Im20150202c & 890 & 7.1 & 100 & 2390 \\
\hline & Im20150202g & 990 & 5.7 & 600 & \\
\hline & Im20150201a & 1190 & 18.3 & & \\
\hline
\end{tabular}

Two profiles were obtained, one along the minor axis (Profile 1) and the other along the major axis (Profile 2) of the JDY maar crater, with five segments in total. The resistivity data were inverted with RES2DINV software. All except one of the inversions were supported by $<10 \%$ RMS errors (the root mean square error; indicating the difference between calculated and measured apparent resistivity) after five iterations. However, the segment Im20150201a had a high RMS error (18.3\%), owing to superficial strong resistivity contrasts resulting from road construction

values $<5 \mathrm{k} \Omega$ ) and the current intensity varied between $1586 \mathrm{~mA}$ and $131 \mathrm{~mA}$. The maximum investigation depth was approximately 160-200 m, depending on the electrode spacing and configuration (Dahlin and Zhou 2004).

The resistivity data were inverted with RES2DINV software (Loke 2002), which applies a model based on the smoothness-constrained least-squares method that allows adjustment of the damping factor (deGrootHedlin and Constable 1990; Sasaki 1992). All except one of the inversions were supported by $<10 \%$ RMS (root mean square) error (indicating the difference between calculated and measured apparent resistivity) after five iterations (Table 1). The segments were concatenated to obtain longer profiles. However, the segment lm20150201a had a high RMS error (18.3\%), owing to superficial strong resistivity contrasts resulting from road construction. Hence, this segment was excluded from the concatenation.

\subsection{Core drilling and laboratory measurements}

The intersection of the two profiles $\left(20^{\circ} 38^{\prime} 5.64^{\prime \prime} \mathrm{N}\right.$, $110^{\circ} 2^{\prime} 15.72^{\prime \prime} \mathrm{E}, 58 \mathrm{~m}$ a.s.l.) was chosen as the drilling location to optimize the correlation with both profiles (Fig. 2), and a core (designated as JDY15B) was obtained at this point by rotary drilling in June 2015. The core was $49.49 \mathrm{~m}$ long with a mean core recovery of $98 \%$, penetrating the entire lacustrine sediments and reaching the fresh volcanic basalts. In the laboratory, the core was split lengthwise into two halves, then visually examined and photographed. Subsamples of the entire core were subsequently obtained by pushing plastic boxes $(2 \times 2 \times$ $2 \mathrm{~cm}$ ) into its surface for measurement of magnetic volume-specific susceptibility ( $\mathrm{k}$ ) using a Bartington

Table 2 Major element concentrations (in wt.\%) of selected samples from the JDY15B core

\begin{tabular}{|c|c|c|c|c|c|c|}
\hline Sample & В03-44 & B06-26 & B09-33 & B20-13 & B39-48 & B48-10 \\
\hline Depth (m) & $\begin{array}{l}2.55 \\
\text { (Unit 7) }\end{array}$ & $\begin{array}{l}5.31 \\
\text { (Unit 7) }\end{array}$ & $\begin{array}{l}8.00 \\
\text { (Unit 6) }\end{array}$ & $\begin{array}{l}18.88 \\
\text { (Unit 4) }\end{array}$ & $\begin{array}{l}39.90 \\
\text { (Unit 3) }\end{array}$ & $\begin{array}{l}48.60 \\
\text { (Unit 1) }\end{array}$ \\
\hline Rock type & Fine sand & Clay & Clay & Diatomite & Scoria & Basalt \\
\hline $\mathrm{SiO}_{2}$ & 71.62 & 73.96 & 66.31 & 66.11 & 51.22 & 50.91 \\
\hline $\mathrm{Al}_{2} \mathrm{O}_{3}$ & 11.23 & 11.60 & 14.53 & 11.14 & 16.20 & 16.10 \\
\hline $\mathrm{TFe}_{2} \mathrm{O}_{3}$ & 8.59 & 5.88 & 8.11 & 6.58 & 11.12 & 10.86 \\
\hline $\mathrm{MgO}$ & 0.16 & 0.37 & 1.43 & 0.75 & 7.89 & 8.55 \\
\hline $\mathrm{CaO}$ & 0.06 & 0.17 & 0.57 & 0.55 & 8.56 & 8.55 \\
\hline $\mathrm{Na}_{2} \mathrm{O}$ & 0.01 & 0.03 & 0.13 & 0.09 & 3.32 & 3.15 \\
\hline $\mathrm{K}_{2} \mathrm{O}$ & 0.05 & 0.07 & 0.44 & 0.53 & 0.75 & 0.81 \\
\hline $\mathrm{TiO}_{2}$ & 2.47 & 2.34 & 1.22 & 1.13 & 1.39 & 1.29 \\
\hline $\mathrm{MnO}$ & 0.02 & 0.02 & 0.03 & 0.10 & 0.15 & 0.14 \\
\hline $\mathrm{P}_{2} \mathrm{O}_{5}$ & 0.03 & 0.05 & 0.06 & 0.14 & 0.21 & 0.20 \\
\hline LOI & 5.19 & 5.33 & 6.72 & 11.59 & -0.65 & -0.41 \\
\hline Total & $99 \%$ & $100 \%$ & $100 \%$ & $99 \%$ & $100 \%$ & $100 \%$ \\
\hline $\mathrm{CIA}^{a}$ & 99 & 98 & 93 & 90 & 56 & 56 \\
\hline
\end{tabular}

1) ${ }^{a}$ Chemical index of alteration $(\mathrm{ClA})=\mathrm{Al}_{2} \mathrm{O}_{3} /\left(\mathrm{Al}_{2} \mathrm{O}_{3}+\mathrm{CaO}+\mathrm{Na}_{2} \mathrm{O}+\mathrm{K}_{2} \mathrm{O}\right) \times 100$

2) Six samples were selected from different lithological units. Samples B03-44, B06-26, and B09-33 from Unit 7 (alluvial facies) and Unit 6 (shallow-lake facies) show depletion of $\mathrm{Mg}, \mathrm{Ca}, \mathrm{K}$ and $\mathrm{Na}$ elements and high $\mathrm{CIA}$ values, indicating extreme weather intensity. Sample B20-13 from Unit 4 (deep-lake facies) shows a relatively high $\mathrm{SiO}_{2}(66.11$ wt.\%), which is a result of abundant diatoms. Samples B39-48 and B48-10 from Unit 3 and Unit 1, respectively, are identical to the Late Cenozoic basalts (quartz tholeiites) in Leizhou Peninsula 
Instrument MS2E sensor in combination with a MS2 control unit. Magnetic susceptibility $(\mathrm{k})$ is an indicator of ferromagnetic mineral concentration and provides a valuable tool for characterizing lithological changes. To estimate productivity, 94 samples at $50 \mathrm{~cm}$ interval were ground to powder and were acid-washed with $10 \% \mathrm{HCl}$ to remove possible inorganic carbon, and then their total organic carbon (TOC) was measured using a Vairo EL cube elemental analyzer (Elementar, Germany). Six selected samples (Table 2) were measured for major element concentrations using a PANalytical Magix PW2424 $\mathrm{X}$-ray fluorescence $(\mathrm{XRF})$ spectrometer (precision $<5 \%$ ). These measurements were all finished in the Sun Yatsen University, excepting that major elements were measured in the ALS Minerals Laboratory of Guangzhou. The geological data from the core provided valuable information that facilitated the interpretation of post-eruptive crater-filling processes and ERT results.

\section{Results}

\subsection{Electrical resistivity tomography (ERT)}

Both profiles indicate the presence of $40-50 \mathrm{~m}$ thick superficial horizontal layers of low resistivity (5$60 \Omega \cdot \mathrm{m}$ ), despite higher resistivity near the surface due to cultivation and road construction (Fig. 3). The resistivity values are lowest $(<10 \Omega \cdot \mathrm{m})$ at depths of 10 $20 \mathrm{~m}$. Under these conductive layers, the inversion models indicate that resistivity rapidly increases to more than $100 \Omega \cdot \mathrm{m}$ (up to $1000 \Omega \cdot \mathrm{m}$ ), although the superficial conductive layers extend deeper into the underlying resistive unit in some places. The ERT measurements also indicate that the thickness of superficial conductive layers varies little inside the crater, at least within the constraints imposed by the spatial resolution of ERT methodology.

Profile 1 shows a thick high resistivity layer $(>100 \Omega \cdot \mathrm{m})$ under the superficial conductive layers, extending across almost all of the crater's minor axis, but split by a conductive column, ca. $400 \mathrm{~m}$ to $500 \mathrm{~m}$ from the NWW starting point (Fig. 3a). The resistivity of this layer tends to be lower in the last $40 \mathrm{~m}$, and in the SEE flank it is thinner and overlies conductive layers $(<60 \Omega \cdot \mathrm{m})$ below depths of ca. $120 \mathrm{~m}$ (Fig. 3a).

In profile 2 (Fig. 3b), the resistivity model shows a similar overall distribution of resistivity to profile 1 , but with some distinct differences. The most striking feature is a larger resistive body (from 200 to $1000 \Omega \cdot \mathrm{m}$ ) at approximately $45 \mathrm{~m}$ depth. The lower part of this large resistive body is ca. $500 \mathrm{~m}$ wide (from 800 to $1300 \mathrm{~m}$ distance) and vertically rooted beyond the maximum depth of investigation. In the upper part, this resistive body rapidly widens, and extends across nearly the entire crater between $40 \mathrm{~m}$ and $120 \mathrm{~m}$ depth, but with a concave upper limit in the centre. The rest of profile 2, below $120 \mathrm{~m}$, is occupied by low-slope conductive layers $(<60 \Omega \cdot \mathrm{m})$.

\subsection{Lithology of the JDY15B core}

The JDY15B core extends to $49.49 \mathrm{~m}$, which consists of $47.92 \mathrm{~m}$ of lacustrine deposits overlying $1.57 \mathrm{~m}$ of pyroclastics and unweathered basaltic lava flow. The lacustrine deposits consist of abundant diatom and clay

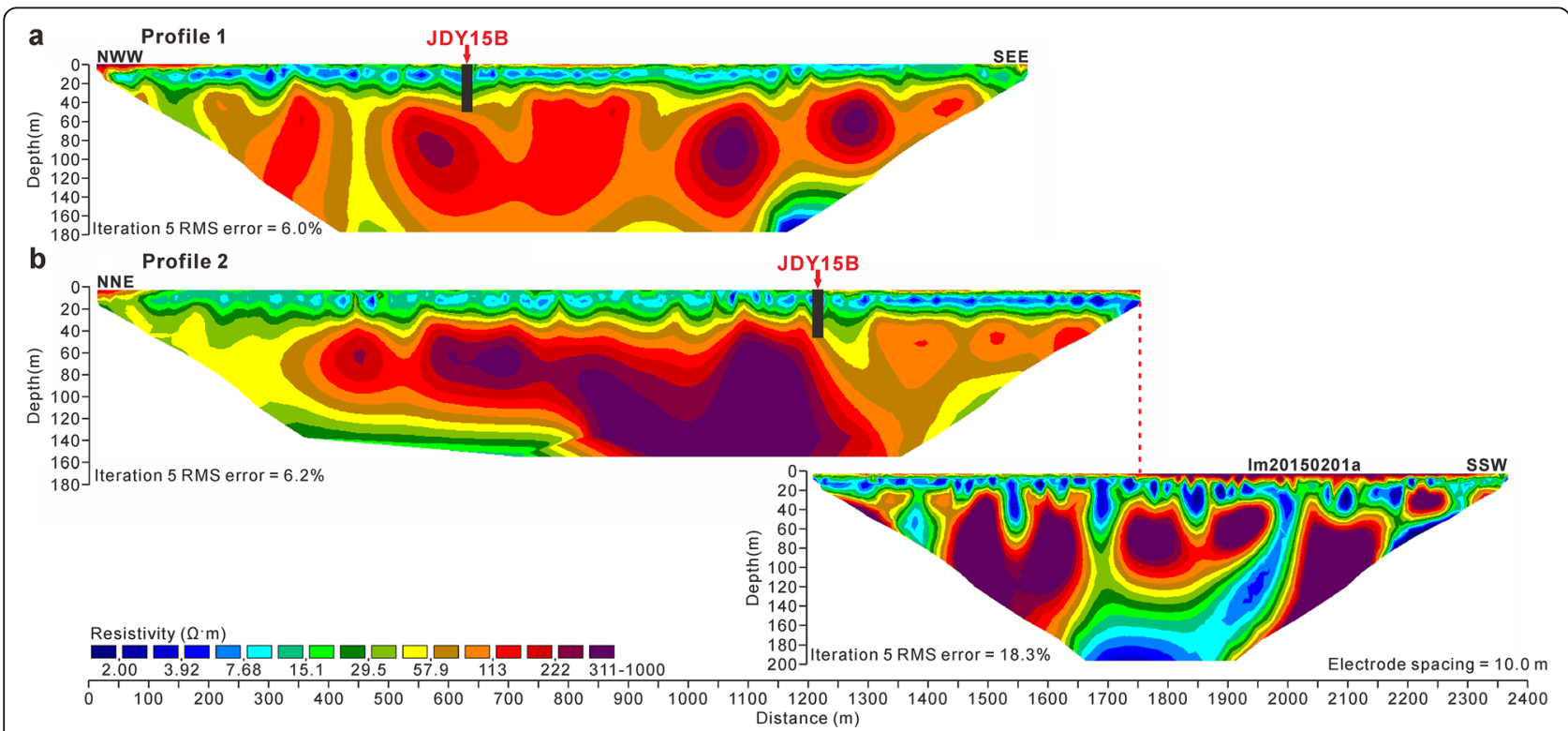

Fig. 3 Electrical resistivity tomography (ERT) models of a Profile 1 and b Profile 2. In Profile 2, the Im20150201a segment is not directly concatenated to the profile to avoid overestimation of resistivity. The location of the JDY15B core is also shown. RMS error means the difference between calculated and measured apparent resistivity 
minerals. The overall succession can be divided into seven units (designated Unit 1 to Unit 7) from the bottom to the top based on the lithology as follows (Fig. 4):

Unit 1 (47.92-49.49 m): fresh basaltic lava flow (Figs. 4, 5a) overlain by a thin layer $(\mathrm{ca} .30 \mathrm{~cm}$ ) of pyroclastics. $\kappa$ values increase abruptly (Fig. 4). Based on the major elements of bulk sample (Table 2), the basaltic lava belongs to quartz tholeiites (Cross et al. 1902), which is one of major types of the Upper Cenozoic basalts in Leizhou Peninsula and Hainan Island (Ho et al. 2000).

Unit 2 (39.95-47.92 m): dark-greenish diatomite laminae (Figs. 4, 5a). The thickness of the lamination generally varies between sub-millimeter to millimeter scales (Fig. $5 \mathrm{a}, \mathrm{d}$ ). $\mathrm{\kappa}$ and TOC values remain stable, i.e., $\mathrm{k}$ is generally between $0.5 \times 10^{-5} \mathrm{SI}$ and $4 \times 10^{-5} \mathrm{SI}$ and TOC is generally between $2 \%$ and $8 \%$ (Fig. 4). This unit is diagnosed as deep-lake facies.

Unit 3 (38.89-39.95 m): dark-greenish grey diatomaceous clay containing abundant pyroclastics (fresh without obvious weathering) (Figs. 4, 5a). The volcanic scoriae (Fig. 5c) are characterized by low $\mathrm{K}_{2} \mathrm{O}(0.75 \%)$ and high $\mathrm{SiO}_{2}$ (51.22\%) (Table 2). $\mathrm{K}$ values are higher but TOC values are lower than adjacent units (diatomite laminae; Fig. 4), due to abundant pyroclastics. This unit is also diagnosed as deep-lake facies.

Unit 4 (11.99-38.89 m): dark-greenish grey diatomaceous clay to diatomite, with some varve-like laminae (27.17-30.24 m; Figs. 4, 5a). $\mathrm{k}$ and TOC values remain relatively stable, similar to Unit 2 . The laminae layer has relatively lower $\mathrm{K}$ value. This unit is also diagnosed as deep-lake facies.

Unit 5 (10.66-11.99 m): water-saturated peat with wood fragments and organic detritus (Figs. 4, 5a, b), characterized by the lowest $\mathrm{\kappa}(0 \mathrm{SI})$ and the highest TOC (up to 30\%) of the entire core. This unit is diagnosed as swamp facies.

Unit $6(6.18-10.66 \mathrm{~m})$ : green-greyish clay minerals (Figs. 4, 5a). $\mathrm{k}$ values generally increase with the depth from ca. $3 \times 10^{-5}$ SI to ca. $10 \times 10^{-5}$ SI. TOC values are low (average 0.2\%). Concentrations of $\mathrm{MgO}$ (1.43\%), $\mathrm{CaO}(0.57 \%), \mathrm{K}_{2} \mathrm{O}(0.44 \%)$ and $\mathrm{Na}_{2} \mathrm{O}(0.13 \%)$ are lower than in the fresh basalt (Unit 1; Table 2). The value of chemical index of alteration (CIA) is 93 (Table 2), indicating extreme chemical weather intensity. This unit is diagnosed as shallow-lake facies.

Unit $7(0-6.18 \mathrm{~m})$ : reddish yellow clay minerals and fine quartz and feldspar sands, with occasionally

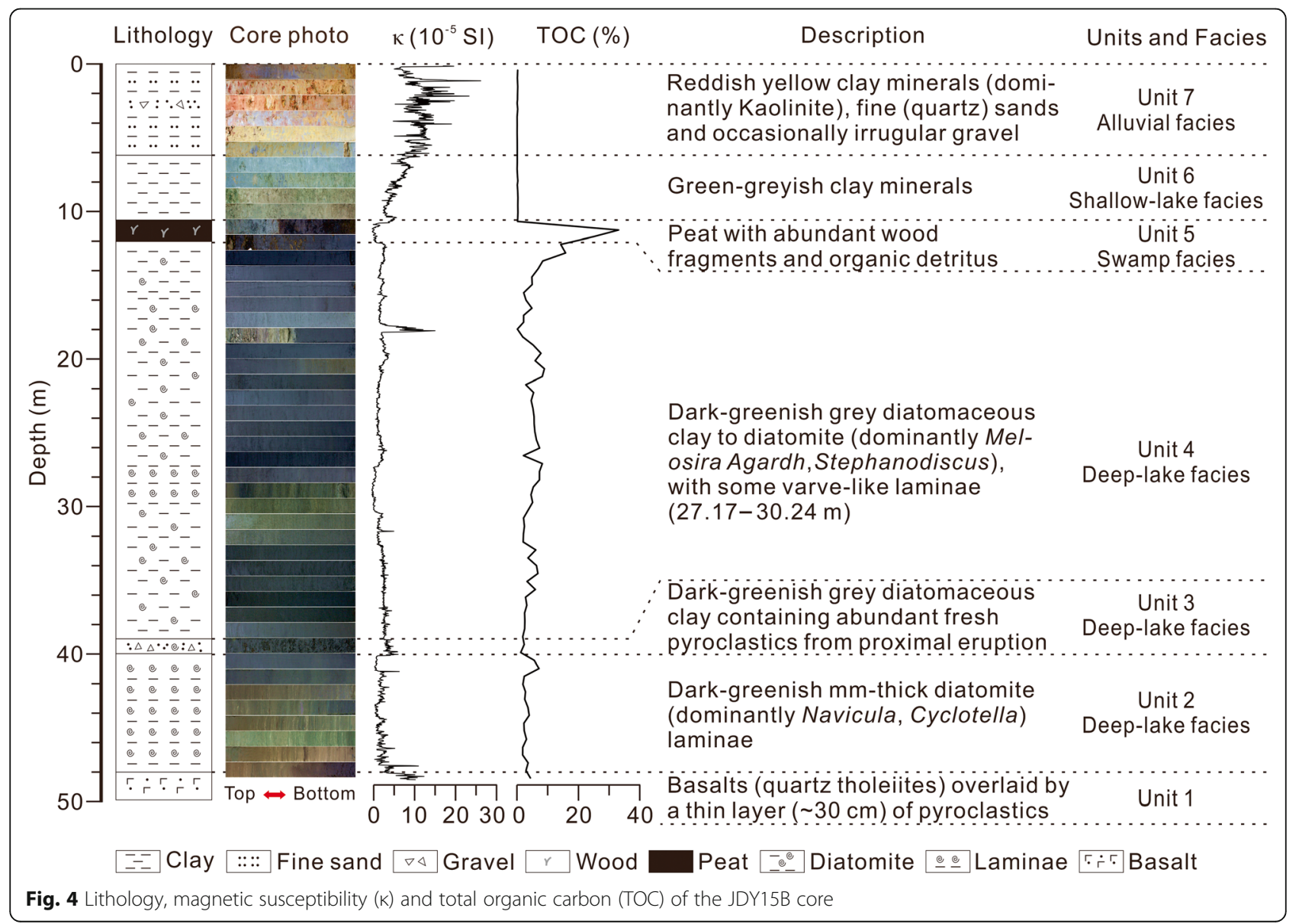




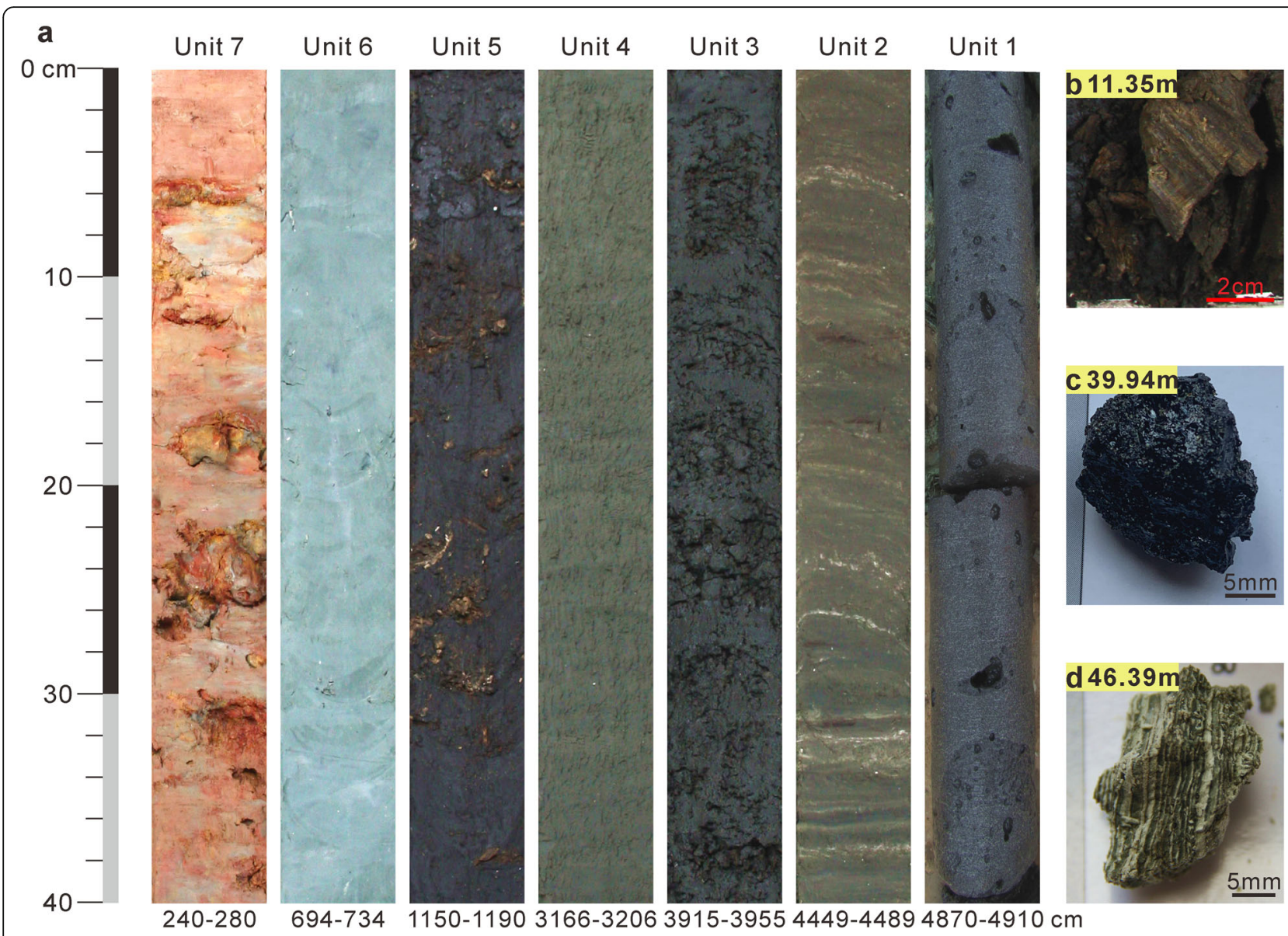

Fig. 5 Photograph of the JDY15 core. a Slices of lithological Units 1-7, showing with the corresponding depth of each slice in the bottom; $\mathbf{b}$ Wood fragments in Unit 5 at 11.35 m depth; c Volcanic scoria in Unit 3 at 39.94 m depth; d Diatomite laminae in Unit 2 at $46.39 \mathrm{~m}$ depth, varying between sub-millimeter to millimeter scales

irregular and poorly rounded gravel at $1.96-3.07 \mathrm{~m}$ depth (Figs. 4, 5a). Elements of $\mathrm{Mg}, \mathrm{Ca}, \mathrm{K}$ and $\mathrm{Na}$ are also extremely depleted. The CIA value is greater than 98 (99 in Table 2), indicating extreme chemical weather intensity. Kaolinite is the dominant clay mineral in regional maar lake sediments under extremely tropical weathering (Zhou et al. 2009; Wang and Lu 2019). This unit has the highest magnetic susceptibility ( $\mathrm{K}$ ) values (up to $26 \times 10^{-5} \mathrm{SI}$ ) of the entire core, while TOC values are close to $0 \%$. This unit is diagnosed as alluvial facies.

\section{Discussion}

\subsection{Post-eruptive evolution history}

From the facies analysis of the maars in the Eifel area (Germany), Pirrung et al. (2003) developed a classification scheme for sedimentary facies division, including five lithozones representing typical stages of maar development in a maar-diatreme structure. These zones are: A (diatreme breccias), B (non-bedded syn-/post-eruptive collapse breccia), C (graded debris flow deposits and turbidites), D (lacustrine laminated sediments with turbidites and debris flow deposits) and E (swamp or peat deposits). Our core from the centre of the JDY crater included sediments almost completely covering post-eruptive development phases, from deep lake to filled basin (Fig. 4). After the eruptions, the crater was rapidly filled with water from meteoric precipitation and/or groundwater because of heavy summer rainfall. On the basis of lithological study, three major stages of the maar post-eruptive evolution can be drawn according to the changes of sedimentary phase.

The first stage of the JDY crater is the transformation into a deep-water maar lake (from Unit 2 to Unit 4) after the eruptions. The big and deep maar lake was a suitable environment for diatom colonization. The most frequent diatom species are Melosira, Stephanodiscus, Navicula and Cyclotella in the lacustrine sediments (Wang et al. 1995). The chemical composition of bulk sample in this stage shows a relatively high $\mathrm{SiO}_{2}$ (ca. 66 wt.\%), which is a result of abundant diatoms. The geochemical analysis of most diatom shells shows that $\mathrm{SiO}_{2}$ content is more than $90 \%$, with minor $\mathrm{Fe}_{2} \mathrm{O}_{3}, \mathrm{TiO}_{2}$, etc. (Feng et al. 
1995). Major element compositions of the volcanic scoriae at $39.9 \mathrm{~m}$ depth are identical to the basaltic lava flow at $48.6 \mathrm{~m}$ depth and the Late Cenozoic basalts in Leizhou Peninsula (Huang et al. 1993; Ho et al. 2000; Wang and $\mathrm{Lu}$ 2019), characterized by low $\mathrm{K}_{2} \mathrm{O}$, low $\mathrm{P}_{2} \mathrm{O}_{5}$ and high $\mathrm{SiO}_{2}$ (Table 2). This implies that the pyroclastics randomly found in the lacustrine sediments (Unit 3) are derived primarily from nearby eruption rather than a distal source. Variations of $\mathrm{\kappa}$ and TOC are small in magnitude (Fig. 4), which is a function of the highly internal productivity of the deep lake environment. During this period, the sediments were primarily controlled by internal lake processes and characterized by high accumulation of autochthonous biogenic silicates (diatom) and organic matter, while allochthonous materials from the crater rim and dust were secondary.

The second stage was a period close to filling up when the lake accommodation for sedimentation reduced and the water level shoaled. Consequently, the lake changed into the shallow condition and finally became a swamp environment. The corresponding sediment layer (Unit 5) is characterized by a high TOC, abundant wood fragments (Fig. 5b) and the extremely low $\mathrm{k}$ (Fig. 4). Organic matter diagenesis may induce the dissolution of ironbearing minerals via iron reduction and consequently, lower $\mathrm{K}$ values of sediments (Sheng et al. 2019). Few diatoms in this stage possibly indicate a high humic acid content. It must be noted that post-eruptive sedimentation does not simply end with swamp or peat deposits, as suggested by Pirrung et al. (2003). Sedimentary environment changes within a maar crater are generally controlled by the crater morphology and water level. The latter is largely affected by regional hydroclimate changes, i.e., the balance between precipitation and evaporation. Therefore, the crater potentially experiences shallow-lake-swamp-alluvial stages repeatedly associated with regional hydroclimate changes, lower water level during the drier glacial and higher water level during the wetter interglacial, till complete filling. Similarly, the Tianyang maar, another large maar, has experienced at least three sedimentary cycles in Leizhou Peninsula (Wang et al. 2012). The present-day annual groundwater table fluctuation can be as high as $3 \mathrm{~m}$ (Zhang et al. 2016). Furthermore, Leizhou Peninsula is located on the frontier of the East Asian summer monsoon, the intensity of which substantially varied during the past glacial-interglacial cycles (Beck et al. 2018) and consequently could influence the water depth and sedimentary environment of the maar craters.

The third stage in our study site from the depth 10.66 $\mathrm{m}$ upward shows a high content of clay minerals and sands with much higher magnetic susceptibility (Unit 6Unit 7; Fig. 4). The depletion of $\mathrm{Mg}, \mathrm{Ca}, \mathrm{K}$ and $\mathrm{Na}$ elements and the high CIA (93-99) indicate a strong chemical weathering condition (Table 2). The sedimentary environment becomes an intermittent shallow lake. The uppermost red clay with gravel is derived from the intermittent local alluvial deposits, in which kaolinite is the dominant clay mineral.

\subsection{Correlation between the ERT results and core stratigraphy}

The resistivity of sediments and rocks depends primarily on the resistivity and content of the pore fluid and the nature of the pore space (Sasaki 1992). Alterations of different lithological units with the depth make ERT suitable to investigate the volcanic structure and sediment sequence of the Jiudouyang maar. The low resistivity of the superficial layers in the two profiles (Fig. 3) is clearly indicative of lacustrine or swamp/peatland sediments, and the JDY15B core provides details of their corresponding lithological composition (Fig. 6). Unit 7 has resistivity values of $20-60 \Omega \cdot \mathrm{m}$, and consists of clay and fine sand with occasional gravel. Unit 6 is composed largely of clay minerals, with $10-20 \Omega \cdot m$ of resistivity. Unit 5 has the lowest resistivity values $(<10 \Omega \cdot \mathrm{m})$, resulting from the high content of water in peat deposits. The diatomaceous clay or diatomite of Unit 2Unit 4 has relatively large resistivity $(10-100 \Omega \cdot \mathrm{m})$, depending on pore water content and degree of compaction. Between depths of $40-50 \mathrm{~m}$, the resistivity values rapidly increase from $60 \Omega \cdot \mathrm{m}$ to $100 \Omega \cdot \mathrm{m}$, and the resistivity of the basaltic lava flow (Unit 1) exceeds 100 (up to 1000) $\Omega \cdot m$.

Generally, the resistivity values of profiles 1 and 2 are both consistent well with the lithology of the JDY15B core (Fig. 6), which validates data acquisition and inversion. Interestingly, the peat deposits (Unit 5) and basaltic lava flow (Unit 1) can be clearly discerned in the ERT imaging profiles (Fig. 6). Similar results have been obtained from analyses of maar lake sediments in the Baruth maar and Messel Pit in Germany (Schulz et al. 2005), and the Mýtina maar in the Czech Republic (Flechsig et al. 2015). These findings suggest that ERT surveys can elucidate the spatial distribution of posteruptive lacustrine sediments in maar craters and help to determine depocentres of drilling cores for palaeoenvironmental research, despite some inevitable error due to the limited spatial resolution of the ERT measurements (Dahlin and Zhou 2004). Our ERT survey of the present JDY crater indicates that the thickness of the post-eruptive sediments is relatively constant $(40-50 \mathrm{~m})$ across the crater (Fig. 3).

\subsection{Subsurface structures and eruptive history}

The resistive layer (> $100 \Omega \cdot \mathrm{m}$ and up to $1000 \Omega \cdot \mathrm{m}$ ) detected below $50 \mathrm{~m}$ depth correlates with lava flow directly overlain by the post-eruptive deep lake sediments 


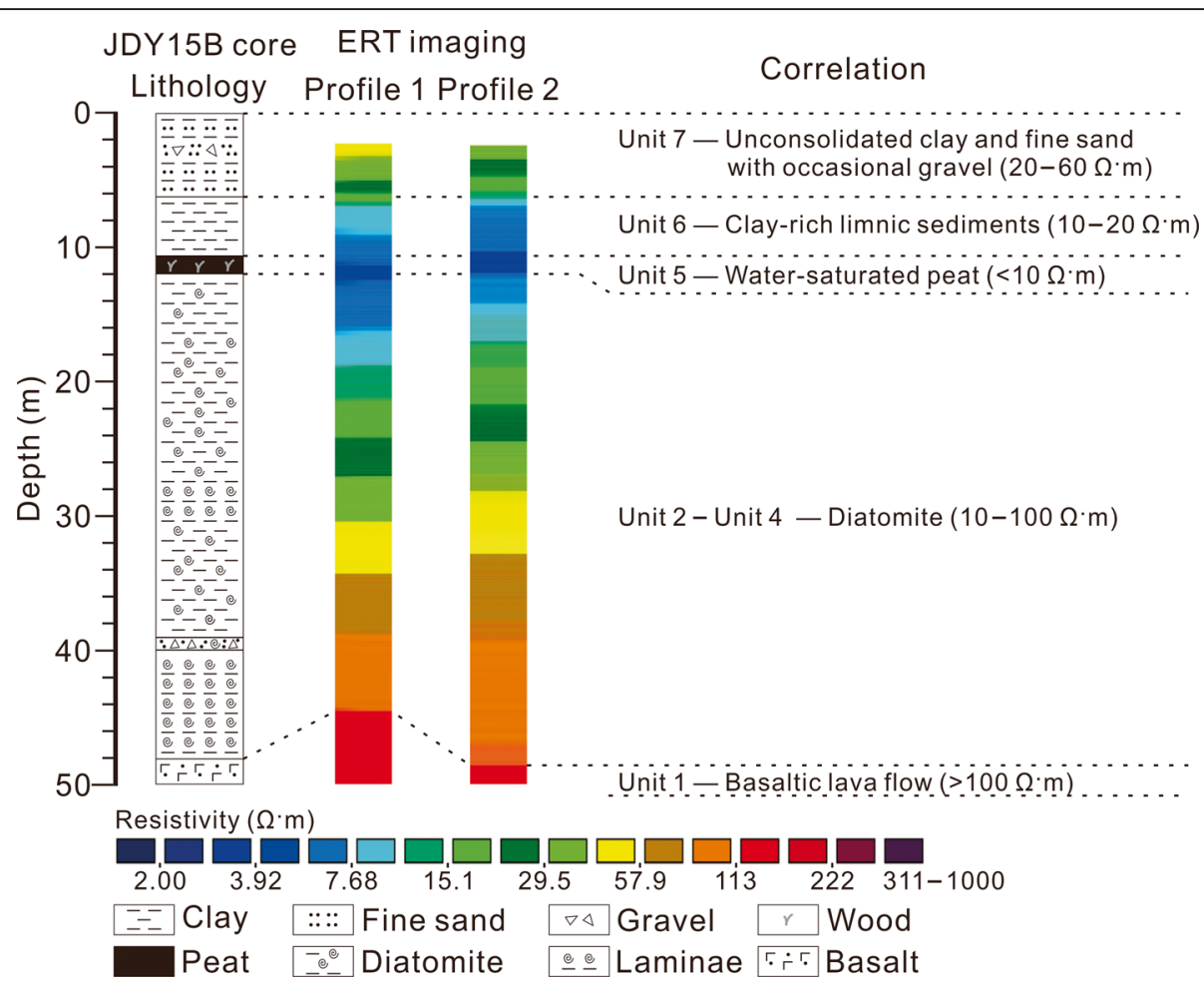

Fig. 6 Correlation between the JDY15B core lithology and the ERT results, revealing coherent lithological characteristics

(diatomite) (Fig. 6). This demonstrates that the eruption was complex rather than a simple type, ending with a Strombolian type and/or lava flow after an initial phreatomagmatic eruption. The ERT results indicate that the lava flow was ca. $70 \mathrm{~m}$ thick (at ca. $50-120 \mathrm{~m}$ depth). In contrast, the infill following a simple phreatomagmatic eruption is often mainly composed of thick syn-/posteruptive diatreme breccia and subsequently lacustrine deposits (White and Ross 2011; Kereszturi et al. 2014). A previous study suggested that syn-/post-eruptive diatreme breccia are poorly distinguished from lacustrine deposits by ERT measurements (Flechsig et al. 2015).

Alternation of eruption styles is common in monogenetic eruptions, which usually start with a phreatomagmatic eruption and then change into magmatic explosive or effusive activity (Kereszturi et al. 2014). Variations in eruption styles occur due to changes in the balance between magma and underground water through exhaustion of water and/or increases in the rising magma. These changes may be driven by both internal (e.g., magma flux and ascent rate) and external factors (e.g., regional tectonic setting and substrate conditions) (Kereszturi et al. 2011; Kshirsagar et al. 2016). In the JDY maar, it is difficult to obtain reliable details about the eruptive products, owing to extreme weathering. According to Huang et al. (1993), the pre-eruptive substrates were dominated by unconsolidated Quaternary sediments, including the Zhanjiang Formation (littoral clay layers) and/or the Beihai Formation (alluvial sandgravel layers), which were saturated with groundwater and were favorable for the onset of the phreatomagmatic eruption (Fig. 7a). However, since volcanic activities peaked in the middle Pleistocene (Huang et al. 1993; Ho et al. 2000), the magma flux and ascent rate of the Hainan Plume were likely high in this period, and eventually, the unconsolidated substrates would not be able to supply sufficient water to fuel phreatomagmatic eruption further. Therefore, the style of eruption shifted to the Strombolian type when groundwater was exhausted and/ or the water/magma ratio decreased (Fig. 7c). Toward the end, the system shifted to 'dry' effusive activity, resulting in lava flow occupying almost the whole maar crater producing a lava lake (Fig. 7d).

An alternative explanation of the infilling sequence indicated by the core is a basaltic flood eruption (i.e., lava flow) followed by a phreatomagmatic eruption. We consider that this is not the situation of the Jiudouyang maar. As the JDY15B core revealed, the basaltic lava flow was overlain by a thin layer $(\mathrm{ca} .30 \mathrm{~cm})$ of pyroclastics and then deep-lake sediments (diatomite). Phreatomagmatic eruption(s) should produce thicker proximal pyroclastic layer than $30 \mathrm{~cm}$, considering the large diameter of the JDY maar. Instead, the thin pyroclastic layer was derived from syn-/post-eruptive fall debris from crater walls. However, a possibility of external origin of lava flow could not be excluded. Since volcanic activities 


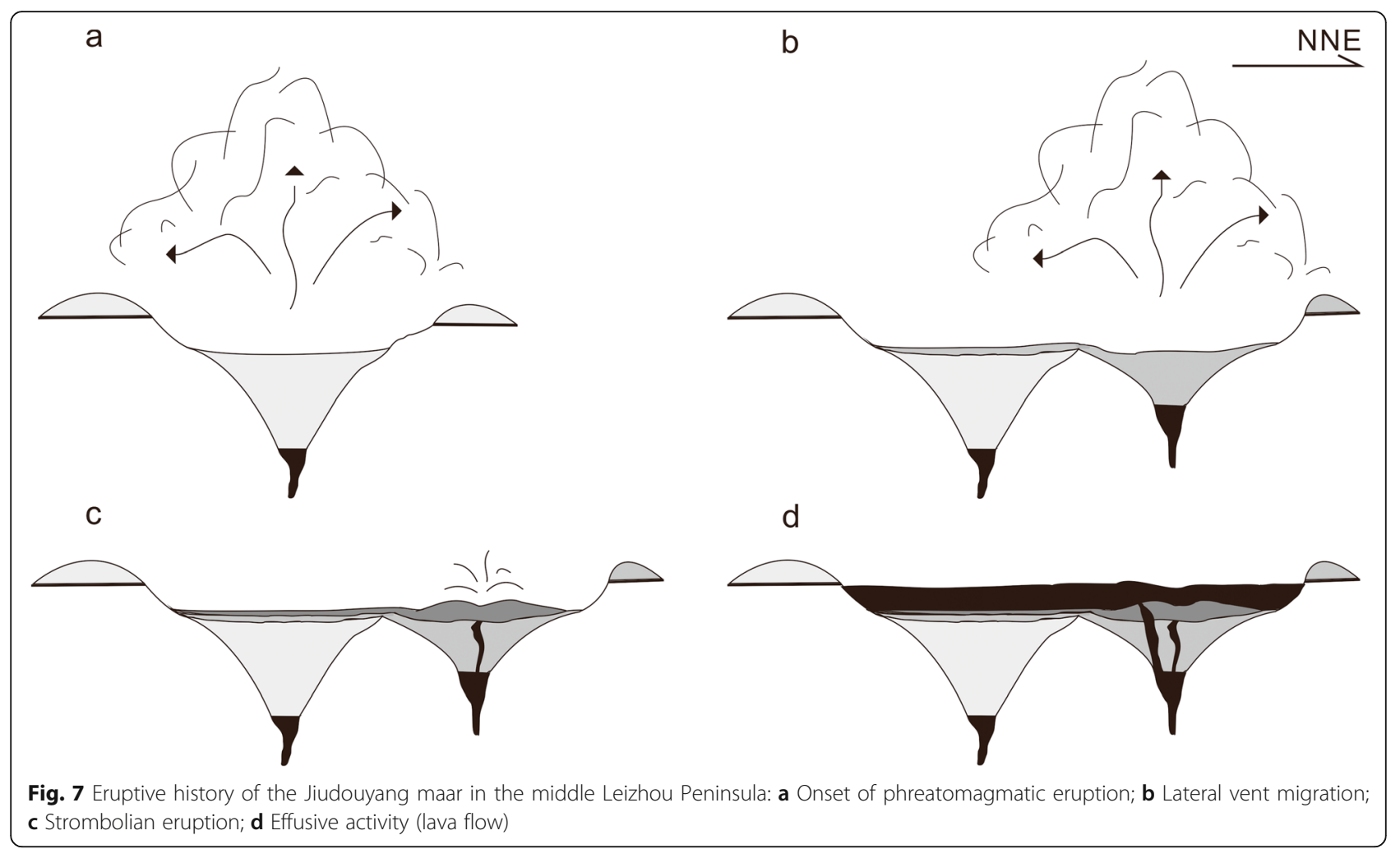

peaked in the middle Pleistocene in Leizhou Peninsula (Huang et al. 1993; Ho et al. 2000), there might be several types of volcanic eruptions (e.g., phreatomagmatic eruption, Strombolian eruption and lava flood eruption) in a small region. In other words, lava flow in the JDY crater might originate from a nearby eruption rather than itself. To clarify this possibility, however, detailed geological and geophysical investigation covering a larger area is needed in further research. Based on available information from ERT results and JDY core lithology, we prefer to alter eruption styles from phreatomagmatic eruption to magmatic explosive or effusive activity in the Jiudouyang maar.

The ERT results indicate that the floor of the initial maar crater is at depth of ca. $120 \mathrm{~m}$ (Fig. 3). The JDY maar is $2.4 \mathrm{~km}$ in average diameter and the present height of its ejecta ring is ca. $20 \mathrm{~m}$. Thus, it now has a diameter/depth ratio of ca. 17, significantly larger than younger maars (ca. 70-10 ka) with diameter/depth ratios ranging from 3 to 7, according to Ross et al. (2011). We suggest that the large diameter/depth ratio of the older crater of the JDY maar (dating from the middle Pleistocene) may be mainly due to widening and shallowing of the crater ring, resulting from a long-term erosion in the tropical climate, as manifested in present-day surface processes. On the other hand, given its elongated shape (major axis to minor axis $=0.6$ ), its large diameter/depth ratio may also be partly due to lateral vent migrations
(Fig. 7b), although the deeper diatreme structures could not be determined in our ERT investigation. Analog experiments suggest that craters with one explosion epicentre tend to be circular and likely reach $560 \mathrm{~m}$ in diameter after tens of explosions and associated collapse, while large and complex craters require lateral vent migration (Sonder et al. 2015; Valentine et al. 2015). Furthermore, multiple coalesced maar craters are also present in Huguangyan and Qingtongyang maars in Leizhou Peninsula, indicating that lateral vent migration commonly occurred during the formation of large maars in the region, in accordance with observations of many large maars around the world (e.g., Németh et al. 2001; Auer et al. 2007; Jordan et al. 2013; Amin and Valentine 2017).

\section{Conclusions}

The combination of geophysical (ERT) technique and geological (stratigraphy and lithology) data analysis allowed us to outline the volcanic structure and spatial distribution of post-eruptive deposits in Jiudouyang maar lake, which is one of the largest maar-diatreme volcanoes in Leizhou Peninsula. Post-eruptive evolution of the maar crater had three major stages: (i) deep lake environment, characterized by high autogenetic diatom productivity; (ii) shallow lake to swamp environment, with very low water levels characterized by very high TOC values and abundant wood fragments; and, (iii) intermittent shallow lake and alluvial deposits, mainly 
composed of clay minerals. The correlation between ERT results and sediment lithology revealed a coherent lithological succession. The organic-rich peat layer had the lowest resistivity values $(<10 \Omega \cdot \mathrm{m})$. The lacustrine silty sediments had higher resistivity values but generally less than $100 \Omega \cdot \mathrm{m}$, while the resistivity values of basaltic lava exceeded $100 \Omega \cdot \mathrm{m}$ (up to $1000 \Omega \cdot \mathrm{m}$ ). The estimated thickness of the post-eruptive sediment overlying the basaltic lave flow was ca. $50 \mathrm{~m}$.

The style of eruption shifted to Strombolian or 'dry' effusive activity due to high magma flux and ascent rate, producing a ca. $70 \mathrm{~m}$-thick basaltic lava flow. An initial phreatomagmatic eruption emplaced in unconsolidated Quaternary sediments produced a bowl-like crater, with a floor at a depth of ca. $120 \mathrm{~m}$. The present-day large diameter to depth ratio and elongated shape of the crater implied possible lateral vent migration during phreatomagmatic eruption and long-term erosion.

Our research extended understandings of the eruptive history and evolution of large maars, and the spatial distribution of post-eruptive sediments in Leizhou Peninsula, and provided new insights into studies of the Cenozoic volcanic activity and the Quaternary palaeoenvironment changes.

\section{Acknowledgements}

We thank Hui-Wei Zheng, Mei-Ling Man, Shi-Fu Li and Hua-Cong Huang in School of Earth Sciences and Engineering, Sun Yat-sen University for their help in the fieldwork. We also thank the local people for their selfless help during the fieldwork. We are grateful to the Editor-in-Chief Prof. Zeng-Zhao Feng and two anonymous reviewers for their valuable comments and suggestions, which have substantially improved the quality of the original manuscript.

\section{Authors' contributions}

$\mathrm{ZZ}, \mathrm{KYH}$, and $\mathrm{CC}$ designed the research; CC and ZZ prepared the manuscript, which was edited by all of the co-authors; CC, LFZ, and LPT did the fieldwork and laboratory analysis; FX provided helpful and constructive advice in the fieldwork and data analysis. All authors read and approved the final paper.

\section{Funding}

This work was supported by the National Key R\&D Program of China (Grant No. 2016 YFA0600500), the National Natural Science Foundation of China (Grant Nos. 41472143 and 41661144003), and the Guangdong Province Introduction of Innovative R\&D Team of Geological Processes and Natural Disasters around the South China Sea (Grant No. 2016ZT06N331).

\section{Availability of data and materials}

The datasets generated and/or analyzed during the current study are not publicly available but are available from the corresponding author on reasonable request.

\section{Competing interests}

The authors declare that they have no competing interests.

Received: 5 June 2020 Accepted: 2 December 2020

Published online: 11 January 2021

\section{References}

Amin, J., and G.A. Valentine. 2017. Compound maar crater and co-eruptive scoria cone in the lunar crater volcanic field (Nevada, USA). Journal of Volcanology and Geothermal Research 339: 41-51.
Auer, A., U. Martin, and K. Nemeth. 2007. The Fekete-hegy (Balaton Highland Hungary) "soft-substrate" and "hard-substrate" maar volcanoes in an aligned volcanic complex - Implications for vent geometry, subsurface stratigraphy and the palaeoenvironmental setting. Journal of Volcanology and Geothermal Research 159: 225-245.

Beck, J.W., W.J. Zhou, C. Li, Z.K. Wu, L. White, F. Xian, X.H. Kong, and Z.S. An. 2018. A 550,000-year record of east Asian monsoon rainfall from ${ }^{10} \mathrm{Be}$ in loess. Science 360 (6391): 877-881.

Blaikie, T.N., L. Ailleres, P.G. Betts, and R.A.F. Cas. 2014. Interpreting subsurface volcanic structures using geologically constrained 3-D gravity inversions: Examples of maar-diatremes, Newer Volcanics Province, southeastern Australia. Journal of Geophysical Research: Solid Earth 119 (4): 3857-3878.

Bolós, X., S. Barde-Cabusson, D. Pedrazzi, J. Martí, A. Casas, M. Himi, and R. Lovera. 2012. Investigation of the inner structure of La Crosa de Sant Dalmai maar (Catalan volcanic zone, Spain). Journal of Volcanology and Geothermal Research 247-248 (9): 37-48.

Brauer, A., C. Endres, and J.F.W. Negendank. 1999. Lateglacial calendar year chronology based on annually laminated sediments from Lake Meerfelder Maar, Germany. Quaternary International 61 (1): 17-25.

Brunner, I., S. Friedel, F. Jacobs, and E. Danckwardt. 1999. Investigation of a tertiary maar structure using three-dimensional resistivity imaging. Geophysical Journal International 136 (3): 771-780.

Chu, G.Q., and J.Q. Liu. 2018. Maar lakes in China and their significance in paleoclimatic research. Acta Petrologica Sinica 34 (1): 4-12 (in Chinese with English Abstract).

Chu, G.Q., Q. Sun, P. Rioual, A. Boltovskoy, Q. Liu, P.Q. Sun, J.T. Han, and J.Q. Liu. 2008. Dinocyst microlaminations and freshwater "red tides" recorded in Lake Xiaolongwan, northeastern China. Journal of Paleolimnology 39 (3): 319-333.

Chu, G.Q., Q. Sun, Q.Z. Zhu, Y.B. Shan, W.Y. Shang, Y. Ling, Y.L. Su, M.M. Xie, X.S. Wang, J.Q. Liu. 2017. The role of the Asian winter monsoon in the rapid propagation of abrupt climate changes during the last deglaciation. Quaternary Science Reviews 177: 120-129.

Cross, W., J.P. Iddings, L.V. Pirsson, and H.S. Washington. 1902. A quantitative chemico-mineralogical classification and nomenclature of igneous rocks. The Journal of Geology 10: 555-690.

Dahlin, T., and B. Zhou. 2004. A numerical comparison of 2D resistivity imaging with 10 electrode arrays. Geophysical Prospecting 52: 379-398.

deGroot-Hedlin, C., and S. Constable. 1990. Occam's inversion to generate smooth, two-dimensional models from magnetotelluric data. Geophysics 55 (12): 1613-1624.

Feng, H., H.F. Zhang, and F.Y. Wang. 1995. Genera, species and chemical composition of diatoms from Guangdong Province. Acta Mineralogica Sinica 15 (1): 29-35 (in Chinese with English Abstract).

Flechsig, C., J. Heinicke, J. Mrlina, H. Kämpf, T. Nickschick, A. Schmidt, T. Bayer, T. Günther, C. Rücker, E. Seidel, and M. Seidl. 2015. Integrated geophysical and geological methods to investigate the inner and outer structures of the quaternary Mýtina maar (W-Bohemia, Czech Republic). International Journal of Earth Sciences 104 (8): 2087-2105.

Flower, M.F.J., M. Zhang, C.Y. Chen, K. Tu, and G. Xie. 1992. Magmatism in the South China Basin: 2. Post-spreading quaternary basalts from Hainan Island. South China. Chemical Geology 97 (1-2): 65-87.

Gebhardt, A.C., M.D. Batist, F. Niessen, F.S. Anselmetti, D. Ariztegui, T. Haberzettl, C. Kopsch, C. Ohlendorf, and B. Zolitschka. 2011. Deciphering lake and maar geometries from seismic refraction and reflection surveys in Laguna Potrok Aike (southern Patagonia, Argentina). Journal of Volcanology and Geothermal Research 201 (1): 357-363.

Gençalioğlu-Kuşcu, C., C. Atilla, R.A.F. Cas, and K. Ilkay. 2007. Base surge deposits, eruption history, and depositional processes of a wet phreatomagmatic volcano in Central Anatolia (Cora Maar). Journal of Volcanology and Geothermal Research 159: 198-209.

Gevrek, A.l., and N. Kazanci. 2000. A Pleistocene, pyroclastic-poor maar from Central Anatolia, Turkey: Influence of a local fault on a phreatomagmatic eruption. Journal of Volcanology and Geothermal Research 95: 309-317.

Graettinger, A.H. 2018. Trends in maar crater size and shape using the global Maar Volcano Location and Shape (MaarVLS) database. Journal of Volcanology and Geothermal Research 357: 1-13. 
Ho, K.S., J.C. Chen, and W.S. Juang. 2000. Geochronology and geochemistry of late Cenozoic basalts from the Leiqiong area, southern China. Journal of Asian Earth Sciences 18 (3): 307-324.

Huang, Z.G., F.X. Cai, Z.Y. Han, J.H. Chen, Y.Q. Zong, and X.D. Lin. 1993. Quaternary volcano in the Leizhou and Hainan region. Beijing: Science Press (in Chinese).

Huang, Z.G., and F.X. Chai. 1994. A new approach to the quaternary volcanicity in the Leiqiong area. Tropical Geography 14 (1): 1-9 (in Chinese with English Abstract)

Jordan, S.C., R.A.F. Cas, and P.C. Hayman. 2013. The origin of a large (>3 km) maar volcano by coalescence of multiple shallow craters: Lake Purrumbete maar, southeastern Australia. Journal of Volcanology and Geothermal Research 254: 5-22.

Kereszturi, G., K. Németh, S.J. Cronin, J.N. Procter, and J. Agustinflores. 2014. Influences on the variability of eruption sequences and style transitions in the Auckland volcanic field, New Zealand. Journal of Volcanology and Geothermal Research 286: 101-115.

Kereszturi, G., K. Németh, G. Csillag, K. Balogh, and J. Kovács. 2011. The role of external environmental factors in changing eruption styles of monogenetic volcanoes in a Mio/Pleistocene continental volcanic field in western Hungary. Journal of Volcanology and Geothermal Research 201: 227-240.

Kshirsagar, P., C. Siebe, M.N. Guilbaud, and S. Salinas. 2016. Geological and environmental controls on the change of eruptive style (phreatomagmatic to Strombolian-effusive) of Late Pleistocene El Caracol tuff cone and its comparison with adjacent volcanoes around the Zacapu basin (Michoacán, México). Journal of Volcanology and Geothermal Research 318: 114-133.

Lebedev, S., S. Chevrot, G. Nolet, and R. van der Hilst. 2000. New seismic evidence for a deep mantle origin of the S. China basalts (the Hainan plume?) and other observations in SE Asia. EOS Transactions AGU 81 (48): 48-148.

Liu, J.Q. 1999. China volcano. Beijing: Science Publishing House (in Chinese).

Liu, J.Q., H.Y. Lu, J.F.W. Negendank, J. Mingram, X.J. Luo, W.Y. Wang, and G.Q. Chu. 2000. Periodicity of Holocene climatic variations in the Huguangyan Maar Lake. Chinese Science Bulletin 45 (18): 1712-1717.

Loke, M.H. 2002. RES2DINV ver. 3.54. Rapid 2-D resistivity and IP inversion using the least square method. Geotomo Software.

Lorenz, V. 1986. On the growth of maars and diatremes and its relevance to the formation of tuff rings. Bulletin of Volcanology 48 (5): 265-274.

Lorenz, V. 2007. Syn- and posteruptive hazards of maar-diatreme volcanoes. Journal of Volcanology and Geothermal Research 159: 285-312.

Martín-Serrano, A., J. Vegas, A. García-Cortés, L. Galán, J.L. Gallardo-Millán, S. Martín-Alfageme, F.M. Rubio, P.I. Ibarra, A. Granda, A. Pérez-González, and J.L. García-Lobón. 2009. Morphotectonic setting of maar lakes in the Campo de Calatrava volcanic field (Central Spain, SW Europe). Sedimentary Geology 222 (1): 52-63.

Martorana, R., G. Fiandaca, A.C. Ponsati, and P.L. Cosentino. 2009. Comparative tests on different multi-electrode arrays using models in near-surface geophysics. Journal of Geophysics and Engineering 6: 1-20.

Mingram, J., G. Schettler, N. Nowaczyk, X.J. Luo, H.Y. Lu, J.Q. Liu, and J.F.W. Negendank. 2004. The Huguang maar lake-a high-resolution record of palaeoenvironmental and palaeoclimatic changes over the last 78,000 years from South China. Quaternary International 122 (1): 85-107.

Mrlina, J., H. Kämpf, C. Kroner, J. Mingram, M. Stebich, A. Brauer, W.H. Geissler, J. Kallmeyer, H. Matthes, and M. Seidl. 2009. Discovery of the first quaternary maar in the Bohemian Massif, Central Europe, based on combined geophysical and geological surveys. Journal of Volcanology and Geothermal Research 182 (1): 97-112.

Németh, K., U. Martin, and S. Harangi. 2001. Miocene phreatomagmatic volcanism at Tihany (Pannonian Basin, Hungary). Journal of Volcanology and Geothermal Research 111: 111-135.

Oms, O., X. Bolós, S. Barde-Cabusson, J. Martí, A. Casas, R. Lovera, M. Himi, B. Gómez de Soler, G. Campeny Vall-Llosera, D. Pedrazzi, and J. Agustí. 2015. Structure of the Pliocene Camp dels Ninots maar-diatreme (Catalan Volcanic Zone, NE Spain). Bulletin of Volcanology 77: 98.

Ortiz, J.E., L. Moreno, T. Torres, J. Vegas, B. Ruiz-Zapata, A. García-Cortés, L. Galán, and A. Pérez-González. 2013. A 220 ka palaeoenvironmental reconstruction of the Fuentillejo maar lake record (Central Spain) using biomarker analysis. Organic Geochemistry 55 (2-Part1): 85-97.

Pirrung, M., C. Fischer, G. Büchel, R. Gaupp, H. Lutz, and F.O. Neuffer. 2003. Lithofacies succession of maar crater deposits in the Eifel area (Germany). Terra Nova 15 (2): 125-132.

Ross, P.S., S. Delpit, M.J. Haller, K. Németh, and H. Corbella. 2011. Influence of the substrate on maar-diatreme volcanoes - An example of a mixed setting from the Pali Aike volcanic field, Argentina. Journal of Volcanology and Geothermal Research 201 (1): 253-271.

Sasaki, Y. 1992. Resolution of resistivity tomography inferred from numerical simulation. Geophysical Prospecting 40 (4): 453-463.

Schulz, R., H. Buness, G. Gabriel, R. Pucher, C. Rolf, H. Wiederhold, and T. Wonik. 2005. Detailed investigation of preserved maar structures by combined geophysical surveys. Bulletin of Volcanology 68 (2): 95-106.

Sheng, M., X.S. Wang, M.J. Dekkers, Y. Chen, G.Q. Chu, L. Tang, J.L. Pei, and Z. Y. Yang. 2019. Paleomagnetic secular variation and relative paleointensity during the Holocene in South China-Huguangyan Maar Lake revisited. Geochemistry, Geophysics, Geosystems 20: 2681-2697.

Sonder, I., A.H. Graettinger, and G.A. Valentine. 2015. Scaling multiblast craters: General approach and application to volcanic craters. Journal of Geophysical Research: Solid Earth 120: 6141-6158.

Sun, Q., and Q.C. Fan. 2005. Study progress on volcanic phreatomagmatic eruption. Acta Petrologica Sinica 21 (6): 1709-1718 (in Chinese with English Abstract).

Tu, K., M.F.J. Flower, R.W. Carlson, M. Zhang, and G. Xie. 1991. Sr, Nd, and Pb isotopic compositions of Hainan basalts (South China): Implications for a subcontinental lithosphere Dupal source. Geology 19 (6): 567-569.

Valentine, G.A., A.H. Graettinger, E. Macorps, P.-S. Ross, J.D.L. White, E. Dohring, and I. Sonder. 2015. Experiments with vertically and laterally migrating subsurface explosions with applications to the geology of phreatomagmatic and hydrothermal explosion craters and diatremes. Bulletin of Volcanology 77: 15.

Valentine, G.A., and J.D.L. White. 2012. Revised conceptual model for maardiatremes: Subsurface processes, energetics, and eruptive products. Geology 40 (12): 1111-1114.

Wang, F.Y., H.F. Zhang, H. Feng, G.X. Chen, D.Q. Wang, and H.P. He. 1995. A mineralogical study of diatomite in Leizhou Peninsula. Chinese Journal of Geochemistry 14 (2): 140-151.

Wang, M., and H.Y. Lu. 2019. Age, geochemical composition and their paleoclimatic implications of the basalt in Leizhou Peninsula, Southern China. Quaternary Sciences 39 (5): 1071-1082 (in Chinese with English Abstract).

Wang, N., Y.Q. Zong, C.R. Brodie, and Z. Zheng. 2012. An examination of the fidelity of n-alkanes as a paleoclimate proxy from sediments of Palaeolake Tianyang, South China. Quaternary International 333: 100 109.

Wei, S.S., and Y.J. Chen. 2016. Seismic evidence of the Hainan mantle plume by receiver function analysis in southern China. Geophysical Research Letters 43: 8978-8985.

White, J.D.L., and P.S. Ross. 2011. Maar-diatreme volcanoes: A review. Journal of Volcanology and Geothermal Research 201 (1): 1-29.

Wu, J., Z.Y. Zhu, C.Q. Sun, P. Rioual, G.Q. Chu, and J.Q. Liu. 2019. The significance of maar volcanoes for palaeoclimatic studies in China. Journal of Volcanology and Geothermal Research 383: 2-15.

Xian, B.Z., Y.X. He, H.P. Niu, J.H. Wang, J.P. Liu, and Z. Wang. 2018. Identification of hydrovolcanism and its significance for hydrocarbon reservoir assessment: A review. Journal of Palaeogeography 7 (1): 11 https://doi.org/10.1186/s42501-018-0010-6.

Yancheva, G., N.R. Nowaczyk, J. Mingram, P. Dulski, G. Schettler, J.F.W. Negendank, J.Q. Liu, D.M. Sigman, L.C. Peterson, and G.H. Haug. 2007. Influence of the intertropical convergence zone on the East Asian monsoon. Nature 445 (7123): 74-77.

Yu, M.M., Y. Yan, C.Y. Huang, X.C. Zhang, Z.X. Tian, W.H. Chen, and M. Santosh. 2018. Opening of the South China Sea and upwelling of the Hainan plume. Geophysical Research Letters 45: 2600-2609.

Zhang, S.H., X.B. Lang, Y.X. Ren, Z.P. Xiao, C.L. Wu, and J.F. Cao. 2016. Dynamic analysis on annual variation of underground water level at 
Leizhou Peninsula in 2014. Pearl River 37 (4): 32-35 (in Chinese with English Abstract).

Zheng, Z., and Z.Q. Lei. 1999. A 400,000 year record of vegetational and climatic changes from a volcanic basin, Leizhou Peninsula, southern China. Palaeogeography, Palaeoclimatology, Palaeoecology 145 (4): 339-362.

Zheng, Z., J.H. Wang, B. Wang, C.L. Liu, H.P. Zou, H. Zhang, Y. Deng, and Y. Bai. 2003. High-resolution records of Holocene from the Shuangchi Maar Lake in Hainan Island. Chinese Science Bulletin 48 (5): 497-502.

Zhou, H.Y., B.S. Wang, H.Z. Guan, Y.J. Lai, C.F. You, J.L. Wang, and H.J. Yang. 2009. Constraints from strontium and neodymium isotopic ratios and trace elements on the sources of the sediments in Lake Huguang Maar. Quaternary Research 72: 289-300.

Zolitschka, B. 1992. Climatic change evidence and lacustrine varves from maar lakes, Germany. Climate Dynamics 6 (3-4): 229-232.

Zou, H.B., and Q.C. Fan. 2010. U-Th isotopes in Hainan basalts: Implications for sub-asthenospheric origin of EM2 mantle endmember and the dynamics of melting beneath Hainan Island. Lithos 116: 145-152.

\section{Publisher's Note}

Springer Nature remains neutral with regard to jurisdictional claims in published maps and institutional affiliations.

\section{Submit your manuscript to a SpringerOpen ${ }^{\circ}$ journal and benefit from:}

- Convenient online submission

- Rigorous peer review

- Open access: articles freely available online

High visibility within the field

- Retaining the copyright to your article

Submit your next manuscript at $\boldsymbol{\nabla}$ springeropen.com 